\title{
模擬降雨流出水採取法（MOS 法）に基づく 路面上のノンポイント 污染源調査 FIELD MEASUREMENTS OF NON-POINT SOURCES ON ROAD SURFACE
USING A MODELED STORM-WATER SAMPLING (MOS) TECHNIQUE
}

\author{
砂田岳彦 ${ }^{1} \cdot$ 二瓶泰雄 ${ }^{2} \cdot$ 坂井文子 ${ }^{3} \cdot$ 吉田拓司 $^{3}$ \\ Takahiko SUNADA, Yasuo NIHEI, Ayako SAKAI and Takushi YOSHIDA \\ 1学生員 学 (工) 東京理科大学大学院 理工学研究科土木工学専攻修士課程 \\ ( ( 278-8510 千葉県野田市山崎 2641) \\ ${ }^{2}$ 正会員 博 (工) 東京理科大学助教授 理工学部土木工学科 (同上) \\ 3非会員 東京理科大学 理工学部土大工学科 (同上)
}

\begin{abstract}
To clarify environments of road deposits, one of main non-point sources in urban area, we have already presented a new technique, named as a modeled storm-water sampling (MOS) technique, in which one can easily obtain road deposits under simulated rainy conditions. By using the MOS technique, we performed the field measurements for road-deposit environments in the watershed of the Oohori River which inflows into Lake Teganuma. In addition, we used a direct sampling (DS) technique with a brush to compare the observed results obtained with the MOS technique. The observed results indicate that the SS and water quality measured with the DS technique are much larger than those with the MOS technique. This result corresponds to the experimental data conducted by the authors. The differences of the road-deposit environments between the residential and industrial area are also discussed.
\end{abstract}

Key Words: non-point source, road deposit, pollutant load, MOS technique, urban area

\section{1.はじめに}

近年の公共用水域では, 水質環境力潢ばしか悪化傾向 にある水域力多く，谷の一因として，都市化に伴う面源 負荷 (ノンポイント污染源) の増加挙(犬゙られる ${ }^{1), 2)}$. ハンポイント活染源の中でも, 路面上の堆積負荷は量的 にも屋根面など他の面源負荷よりも大きく ${ }^{3)}$, また , 最 近では, 路面堆積塵埃に微量有害物質が含まれているこ とか指摘されている ${ }^{4)}{ }^{5)}$.このようなことから，路面堆 積負荷特性を把握するために，これまでに多くの調査研 究か行われている. 乥こでは, 路面堆積塵埃を採取する 際には，作業か簡便なため，ブラシや掃除機を用いて直 接堆積物を採取する方法 (堆積物採集法) がよく用いら れる1).しかしながら，この方法では，実際に降雨時に 流出する成分よりも多くの堆積物を採取している可能性 か高く, 得られたサンプルの代表性に問題がある.さら に，このような方法に基ついて得られた路面堆積負荷に 関する知見 ${ }^{1)}$ がどこまで有効であるかは疑問である.

光れに対して，著者らは，簡易的に降雨流出状況を再 現しつつ，路面堆積塵埃を採取することか容易である， 模擬降雨流出水採取法 (MOdeled Storm-water sampling technique，以下, 模擬降雨法 (MOS 法) と呼引汭を提案 している(6)，7)。光こでは，室内実験を通して，模擬降雨
法力降雨流出過程を概ね模擬した形て路面塵埃を採取で きることか検証されている7). また，この模擬降雨法を 用いて多時点・多地点調査を行い, 路面上の定点におけ る路面堆積塵埃の時間変動特性と気象条件 (降雨量) と の関連性を検討するとともに, 道路上の堆積塵埃量の平 面マップを作成した6)，7).このように，多時点・多地点 調査を簡便かつ精度良く行うことが可能な模擬降雨法を 用いて, 今後, 路面堆積負荷に関する既存の知見の見直 しや流域全体にわたる広域調査を行うことは有用である． このような研究背景に基ついて, 本論文ては, 模擬降 雨法に基ついて, 都市河川の流域全体にわたる路面上の ノンポイント污染源調査を実施することを試みる .ここ ての調査対象は, 富栄養化力著しい千葉県手賀沼への主 要流入河川である大堀川流域全体とし, 用途地域毎の堆 積負荷に着目して，住居系地域と工業系地域に光れ光れ 観測地点を設けている.ここで得られた調査結果に基づ (て，まず，1）模擬降雨法及ひ既存の堆積物採集法に より得られた堆積塵埃環境を比較・検討する . また，光 の結果に基ついて，2) 工業系地域の堆積負荷量が他の 地域 (住居系地域等) よりも非常に大きい, という既存 の知見 ${ }^{1)}$ の適用性について検討する .

\section{2. 模擬降雨法の概要}




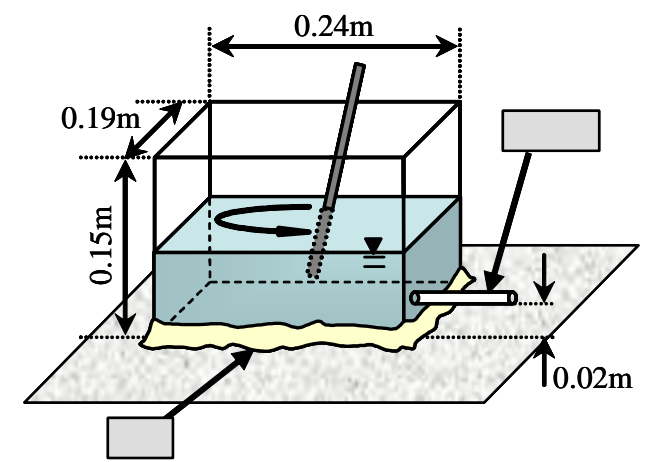

図- 1 模擬降雨法で用いる装置の概要

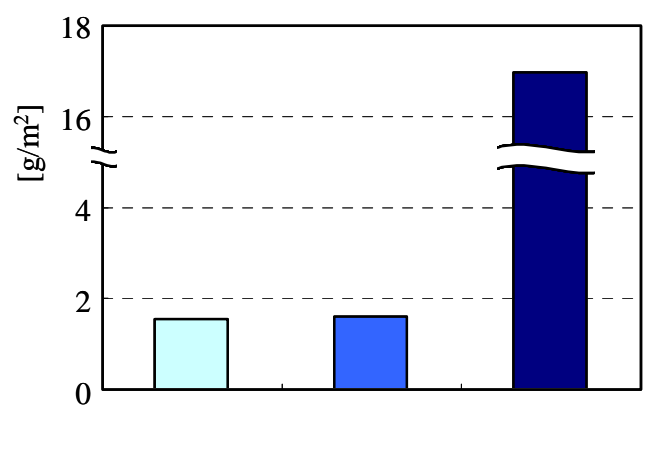

図-2人工降雨法と模疑降雨法 堆積物採集法により得られ た塵埃質量 (散布量 $21.2 \mathrm{~g} / \mathrm{m}^{2}$ の場合) ${ }^{7)}$

模擬降雨法ては簡便に降雨流出状况を模擬するために， 図- 1 に示すプラスティック製容器を路面上に突き立て て, 光の容器内に注入された水を覞拌棒により1秒間に 2 往復程度の速さて攪拌し，水中を浮遊する路面鹿埃を 採取している.これまで用いていた容器の形状は円筒で あるが6)，縁石により角となることが多い路肩部での堆 積物採取を行い易くするために容器形状を長方形として いる.この容器を用いた作業手順としては，

(1)パテによりプラスティック製容器を路面に接着する . (2)容器内に蒸留水 $2 L$ を注入する .

(3)容器内の水を攂拌しながら取水口より採水する . なお, この一連の作業を行うのに, 5 分程度かかる。

模擬降雨法力降雨流出過程をどの程度模擬できている かを調べるために，著者ら 卜上に塵埃を散布し, 模擬降雨法と堆積物採集法により 路面鹿埃を採取する，という室内実験を行った．乥こで は, 降雨状況を再現している人工降雨法も比較のために 適用した . 各手法により得られた単位面積当たりの塵埃 質量を比べたところ (図-2 ),模鄇降雨法の結果は人工 降雨法と同程度となるのに対して , 堆積物採集法の結果

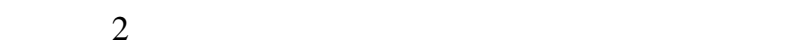
これより，堆積物採集法は降雨時に流出してくる成分よ りも非常に大きな塵埃量を取得しているのに対して , 模 擬降雨法は概ね降雨流出条件を模擬した形て路面塵埃を 採取し得る手法であることが分かる。

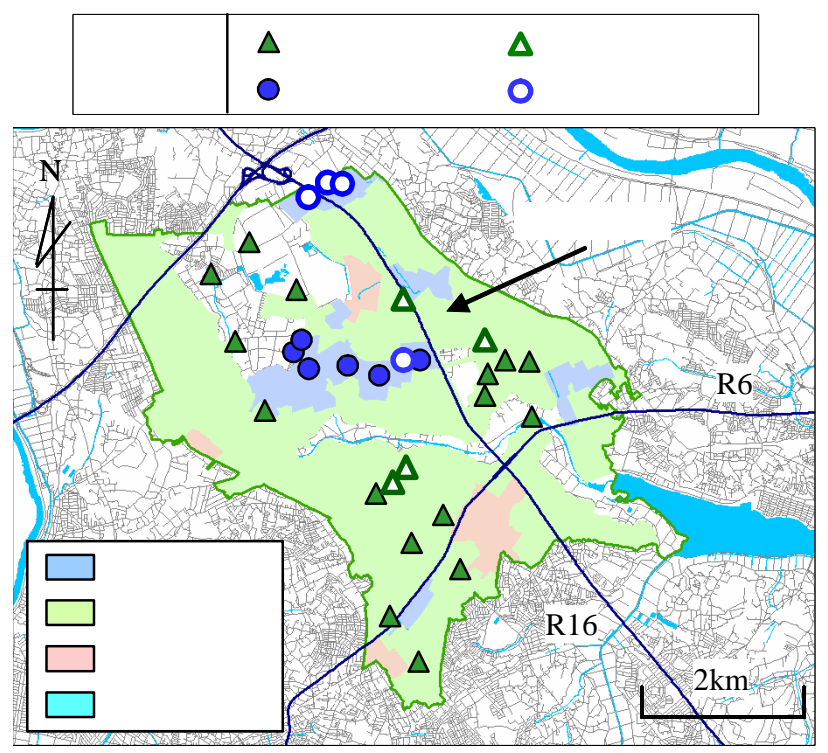

図-3 大堀川流域と調査地点

\section{3. 現地調査の概要}

\section{（1）大堀川流域について}

模擬降雨法を用いた路面上のノンポイント污染源調査 は，千葉県流山市，柏市を流下し手賀沼西部に注ぎ入む 大堀川の流域において行われた .この大堀川流域は, 図 一 3 に示すように, 面積 $31.2 \mathrm{~km}^{2}$ であり，土地利用特性 としては約 80\%か洼地となっている.図中には, 用途 地域別に住居系地域（第 1 種住居専用地域，第 2 種住居 専用地域，住居地域，準住居地域) と工業系地域 (準工 業地域，工業地域，工業専用地域），商業系地域 (商業地 域，近隣商業地域)に色分けされて表示している.色が 表示されていない部分は，市街化調整区域である .これ より，住居系地域か大部分を占めており $(68 \%) ， ま た ，$ 工業系地域 $(10 \%)$ もいくつか点在している.

\section{（2）調査内容}

和田 ${ }^{1)}$ は用途地域別に路面堆積負荷を検討し，工業系 地域の負荷量か他の地域よりも大きいことを指摘してい る. そここで, 模擬降雨法を用いて用途地域毎の路面堆積 負荷特性を明らかにするために, 観測地点は, 図一 3 に

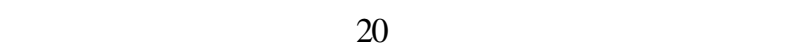
地域 10 点 (図中○，○印)，という 30 地点とする.各観 測地点では, 路肩部の 2 箇所と路肩から $1.0 \mathrm{~m}$ 離れた中 央部の 1 箇所において路面堆積塵埃を採取している.こ の際，路肩部における測定箇所としては, 目視により， 周辺の中て最も堆積量の大きい場所が選定されている . このような現地観測を 2005/6/30〜7/1，7/21，7/29，8/29 の計 4 回行っている . 本論文では, 紙面の都合上 , 7/21 に行われた路肩部における結果のみを記述する。 


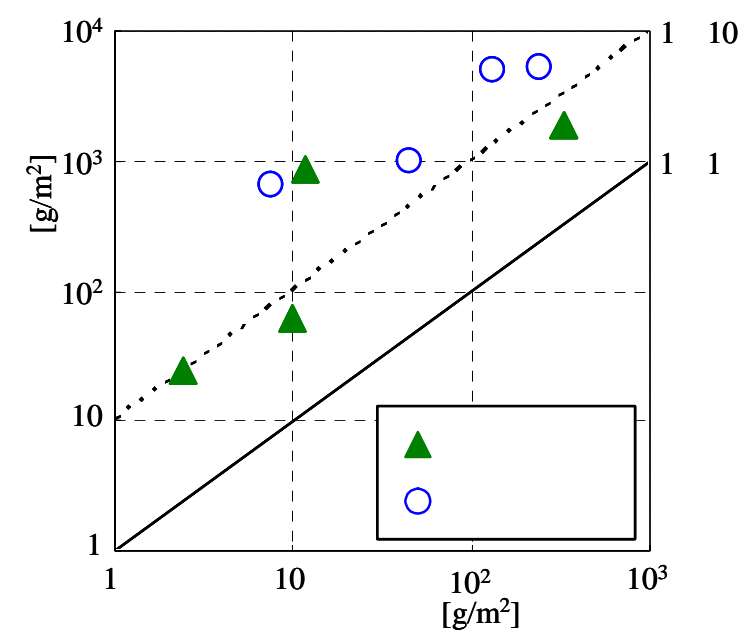

( a) SS

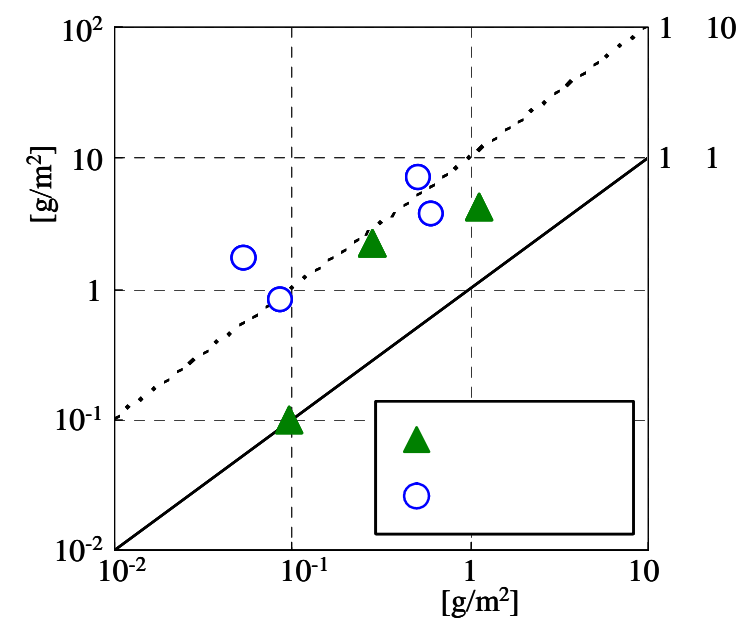

(c) P-N

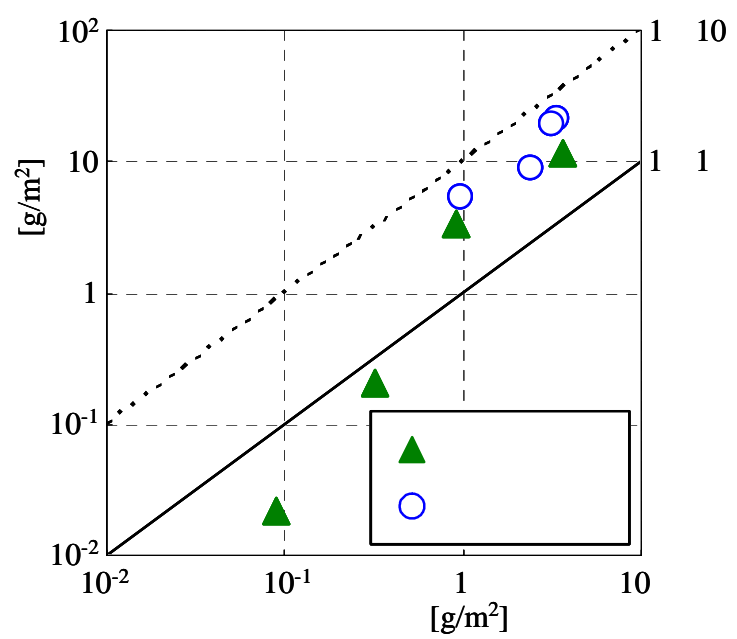

( b) P-COD

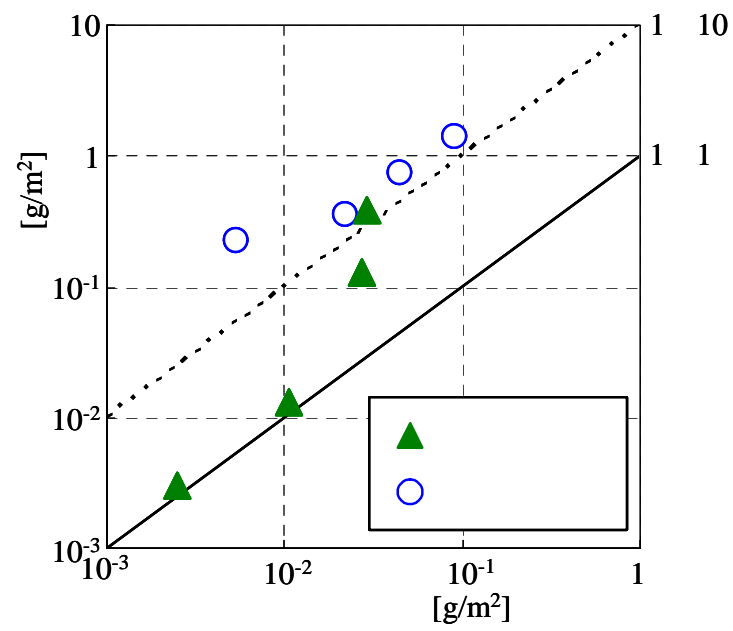

(d) P-P

図-4 模擬绛雨法と堆積物採集法によるSS や水質濃度の相関図（単位面積当たりに換算して表示）

採取されたサンプル水の分析項目としては , 全てのサ ンプルに対しては濁度とし，一部についてはSS ,COD， 室素 , リンとする . 濁度の計測には, 多項目水質計 (WQC-24，東亜ディーケーケー(妹製) を用いる. 弚の 他の水質項目に関しては, 下水試験方法帛に基づて分

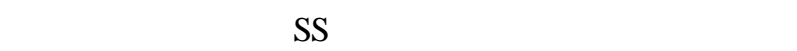
全サンプル水に対して得られた濁度値を SS に変換して いるなお,COD と窒素，リンに関しては, 全成分(T-COD， T-N , T-P) と溶存態成分 (D-COD , D-N , D-P) を分析 し, 両者の差として懸濁態成分 (P-COD , P-N , P-P) を 算出している.

さらに, 模擬降雨法と堆積物採集法により得られる路 面鹿埃環境を比較するために，前述した模擬降雨法によ る調査と同期する形でブラシを用いた堆積物採集法によ る調査を実施した . 調査日は，模擬降雨法の第二回目 (7/21) であり，調査地点は，図一３に示すように，住 居系，工業系地域ともに4地点 (図中 $\triangle$, ○印) とする . ブラシにより路面鹿埃を採取する面積は, 模擬降雨法と
同じ面積 $\left(0.045 \mathrm{~m}^{2}\right)$ としている.採取された路面塵埃の 分析項目は, 模擬降雨法の場合と同一である.

\section{4 . 模擬降雨法と堆積物採集法による路面塵埃採取 状況の比較}

\section{（１）生データの比較}

模疑跭雨法と堆積物採集法により，同一地点・同時に 採取された路面堆積塵埃環境を比べるために，住居系地 域 4 地点と工業系地域 4 地点における両手法の計測結果 の生データを図ー 4 に示す .ここでは,SS と水質項目の 懸濁態農度 (P-COD , P-N , P-P) に関する結果を, 単位 面積当たりの質量に換算して図示している . 図中の横軸 は模擬降雨法による計測值，䋡連由は堆積物採集法による 計測值を表しており，また，住居系地域 ( 系地域 (○印) を分けて表示している.これを見ると， 大局的には，堆積物採集法により採取された SS や水質 項目の懸濁態濃度は 模擬降雨法の計測值よりも大きく， 
表- 1 模疑降雨法と堆嫧物採集法による計測結果の平均値 (単位: $\mathrm{g} / \mathrm{m}^{2}$ )

\begin{tabular}{|c|c|c|c|c|}
\hline & & $\begin{array}{c}\text { (1) } \\
\text { 模擬降雨注 }\end{array}$ & $\begin{array}{c}\text { (2) } \\
\text { 堆積物採集法 }\end{array}$ & (2)/(1) \\
\hline \multirow{3}{*}{ SS } & 工業系 & 106.1 & 2946.3 & 27.8 \\
\hline & 住居系 & 87.39 & 705.4 & 8.1 \\
\hline & $\begin{array}{l}\text { 平均 } \\
\end{array}$ & 96.76 & 1825.9 & $\begin{array}{l}18.9 \\
\end{array}$ \\
\hline \multirow{3}{*}{$\mathrm{P}-\mathrm{COD}$} & 工業系 & 2.509 & 13.44 & 5.4 \\
\hline & 住居系 & 1.257 & 3.841 & 3.1 \\
\hline & 苹均 & $\overline{c 1.883}$ & 8.640 & $\begin{array}{c}4.6 \\
\end{array}$ \\
\hline \multirow{3}{*}{ P-N } & 工業系 & 0.315 & 3.326 & 10.6 \\
\hline & 住居系 & 0.374 & 1.646 & 4.4 \\
\hline & 更均 & 0.345 & 2.486 & 7.2 \\
\hline \multirow{3}{*}{ P-P } & 工業系 & 0.0410 & 0.6751 & 16.4 \\
\hline & 住居系 & 0.0172 & 0.1325 & 7.7 \\
\hline & 苹均 & $\overline{0.0291}$ & 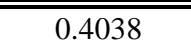 & $\begin{array}{l}13.9 \\
\end{array}$ \\
\hline
\end{tabular}

その傾向は工業系地域の方か顕著である . 具体的には， SS については, 全地点において, 堆積物採集法による計 測值の方力模擬降雨法の結果よりも1〜2オーダ一程度 大きくなっている．また，P-Nや P-P に関しては，堆積 物採集法の方が1オーダ一程度模擬降雨法よりも大きい が , 両者の結果か洞程度となるサンプルも住居系地域に おいて1，2箇所存在する .さらに,P-CODについても， 他の項目と同樣に，堆積物採集法の計測結果の方か湘対 的に模擬降雨法よりも大きいものの，乥の逆の結果とな る測定点も 2 地点存在し，これらはいずれも住居系地域 である。

このように，住居系地域の何点かでは，両手法による 結果は大差なかったものの，残りの住居系地域や全ての 工業系地域の調査点では, 堆積物採集法の計測值の方が 明らかに模擬降雨法の結果よりも大きいことが分かる. 図一 2 に示しているように , 著者らか行った室内実験に より，堆積物採集法による路面塵埃の採取量は，同一条 件における模擬降雨法よりも1オーダー程度大きいとい う結果は得られており，本調査により，実験結果と類似 した傾向か樣々な地点において行われた現地調査結果に おいても確忍された .

\section{( 2 ）平均值の比較}

二つの採取法に基ついて得られた結果をより定量的に 比較するために，SS や水質濃度に関する平均值をまとめ た結果を表一 1 に示す.ここで，住居系地域の地点と 工業系地域の地点, 全地点について, 光れ光れ平均值が 表示されている.これを見ると，まず，ブラシを用いた 堆積物採集法に関しては，工業系地域の方が全般的に住 居系地域よりも大きい . 両者の比率 (=工業系地域の計 測值/住居系地域の計測值) は2.0〜5.1 となっている.
表- 2 SS 中の COD , 窒素, リン含有量 (単位 : $g / k g$ )

\begin{tabular}{|c|c|cc|}
\hline & & 模擬降雨法 & 堆積物採集法 \\
\hline \multirow{3}{*}{ P-COD/SS } & 工業系 & 96.840 & 6.602 \\
& 住居系 & 39.854 & 3.601 \\
\cline { 2 - 4 } & 平均 & 68.347 & 5.101 \\
\hline \multirow{3}{*}{ P-N/SS } & 工業系 & 3.878 & 1.389 \\
& 住居系 & 12.434 & 1.675 \\
\cline { 2 - 4 } & 平均 & 8.156 & 1.532 \\
\hline \multirow{3}{*}{ P-P/SS } & 工業系 & 0.524 & 0.281 \\
& 住居系 & 1.165 & 0.212 \\
\cline { 2 - 4 } & 平均 & 0.844 & 0.246 \\
\hline
\end{tabular}

和田 ${ }^{1)}$ は工業系地域における SS や水質濃度は1オーダ 一程度住居系地域よりも大きいとしている . 本論文での 結果は, 和田 ${ }^{1)}$ 力指摘するほどの両地域間の差は見られ ないが, 定性的な傾向は一致している。一方, 模擬降雨 法により得られた，住居系地域と工業系地域における塵 埃環境を比較すると，工業系地域の方力淮居系地域を上 回ることが多いものの, 弚の比率は $0.8 〜 2.4$ と堆積物採 集法の場合と比べて小さい .

また , この表を用いて, 図一 4 と同樣に, 模擬降雨法 と堆積物採集法における計測值を比較する.堆積物採集 法の計測值を模擬降雨法の結果て基準化すると，この割 合は, 工業系地域で 5.4〜27.8, 住居系地域では, 3.1 〜8.1 となっており，前述したように，堆積物採集法の方 力糢擬降雨法よりも多くの路面堆積物を採取しており， 产の傾向は，工業系地域において顕著となっていること か汾かる. 水質項目別に見ると, 両手法の違いは SS が 最も大きいことが分かる .

このように堆積物採集法ては ,ブラシなどを用いて， 調査対象領域の全ての路面塵埃を採取してしまうが, 光 の中には, 降雨時においても流出せずに路面上に堆積し 続ける塵埃も多く含まれている.特に , 今回の路肩部の ように多量の塵埃力堆積している場所ては, 道路表面が 一部啋れるほどの鹿埃がある程度の厚さをもって堆積し ている. 兴のような場合には, 実際には, 塵埃の堆積層 の表面部分しか降雨時に流出しないにも関わらず，堆積 物採集法では全て路面堆積塵埃を採取していることとな る，一方，模擬降雨法ては，降雨時流出状況を模擬的に 再現して, 塵埃の堆積層表面の部分から離脱した塵埃の みを採取している. 兴のため, 両手法により採取された SS や水質項目の懸濁態濃度は大きく異なったものと考 えられる。

また , 表- 2 は, SS 中の COD , 室素 , リン含有量に つて，模擬降雨法と堆積物採集法により得られた結果 の平均值を示している.ここでも住居系地域と工業系地 
表-3 大堀川流域における路面堆積負荷特性

( a) COD

\begin{tabular}{|c|c|c|c|c|c|c|}
\hline & \multicolumn{2}{|c|}{$\mathrm{T}-\mathrm{COD}\left[\mathrm{g} / \mathrm{m}^{2}\right]$} & \multicolumn{2}{c|}{ D-COD $\left[\mathrm{g} / \mathrm{m}^{2}\right]$} & \multicolumn{2}{c|}{ P-COD $\left[\mathrm{g} / \mathrm{m}^{2}\right]$} \\
\hline & レンジ & 平均 & レンジ & 平均 & レンジ & 平均 \\
\hline 工業系地域 & $0.140 \sim 3.839$ & 1.218 & $0.064 \sim 0.435$ & 0.155 & $0.040 \sim 3.403$ & 1.063 \\
住居系地域 & $0.173 \sim 3.910$ & 0.964 & $0.058 \sim 0.380$ & 0.144 & $0.067 \sim 3.717$ & 0.820 \\
\hline
\end{tabular}

(b) 窒素

\begin{tabular}{|c|c|c|c|c|c|c|}
\hline & \multicolumn{2}{|c|}{$\mathrm{T}-\mathrm{N}\left[\mathrm{g} / \mathrm{m}^{2}\right]$} & \multicolumn{2}{c|}{$\mathrm{D}-\mathrm{N}\left[\mathrm{g} / \mathrm{m}^{2}\right]$} & \multicolumn{2}{c|}{$\mathrm{P}-\mathrm{N}\left[\mathrm{g} / \mathrm{m}^{2}\right]$} \\
\hline & レンジ & 平均 & レンジ & 平均 & レンジ & 平均 \\
\hline 工業系地域 & $0.015 \sim 0.675$ & 0.185 & $0.015 \sim 0.098$ & 0.035 & $0.008 \sim 0.607$ & 0.166 \\
住居系地域 & $0.021 \sim 1.195$ & 0.219 & $0.011 \sim 0.075$ & 0.030 & $0.009 \sim 1.121$ & 0.199 \\
\hline
\end{tabular}

( c) リン

\begin{tabular}{|c|c|c|c|c|c|c|}
\hline & \multicolumn{2}{|c|}{$\mathrm{T}-\mathrm{P}\left[\mathrm{g} / \mathrm{m}^{2}\right]$} & \multicolumn{2}{c|}{$\mathrm{D}-\mathrm{P}\left[\mathrm{g} / \mathrm{m}^{2}\right]$} & \multicolumn{2}{c|}{$\mathrm{P}-\mathrm{P}\left[\mathrm{g} / \mathrm{m}^{2}\right]$} \\
\hline & レンジ & 平均 & レンジ & 平均 & レンジ & 平均 \\
\hline 工業系地域 & $0.0012 \sim 0.0984$ & 0.0272 & $0.0007 \sim 0.0076$ & 0.0027 & $0.0006 \sim 0.0921$ & 0.0245 \\
住居系地域 & $0.0025 \sim 0.0814$ & 0.0247 & $0.0011 \sim 0.0058$ & 0.0022 & $0.0011 \sim 0.0789$ & 0.0225 \\
\hline
\end{tabular}

域及び弚の平均に分けて表示している．これを見ると， 全ての水質項目，地域において，堆積物採集法による結 果力模擬降雨法よりも小さいことか汾かる.このような 調査結果より,両手法による採取物は, SS 等の量产のも のか異なるのみならず, 採取物の質も大きく変化してい ることが分かる。

\section{5. 大堀川流域における路面堆積負荷特性}

\section{（1）住居系地域と工業系地域の比較}

大堀川流域の住居系地域と工業系地域における路面堆 積負荷特性を比較するために，模擬降雨法により得られ た COD と室素,リンに関する平均值及び光のレンジ (最 小值から最大值) をまとめたものを表-3に示す .ここ では, 3 つの水質項目ともに，全成分，溶存態成分，懸 濁態成分について記述している.この表から，9 つの水 質濃度の平均値を住居系地域と工業系地域で比べると， 一部のデータを除けば, 大部分は工業系地域における濃 度值力相対的に大きくなっている．しかしながら，弚の ような違いは, 和田 ${ }^{1)}$ 力指摘しているようなオーダーが 異なるほどてはなく，両者の結果はほぼ同程度と見なし てよい.このように, 降雨流出状況を再現している模擬 降雨法を用いることにより，路面堆積負荷に関する既存 の知見と大きく異なる結果力得られている.なお，この 表における懸蜀態濃度の結果と, 表- 1 の濃度值は同一 となっていない．これは，表-1ではブラシを用いて路 面鹿埃を採取した地点 (図-3 中の住居系・工業系各々 4地点) のみの結果から算出したのに対して, 表-3で は全観測点 (合計30地点) の結果から算出したためであ る。
また , 全成分に対する溶存態成分と懸濁態成分の寄与 を見ると，COD，T-N ，T-P ともに，懸蜀態成分が大部分 を占めているものの, 乥の割合はリンか㵊も高く, 室素 か最も低いことか汾かる.さらに, 各水質項目について 平均值とレンジを比べると，平均值に比べてレンジの幅 か広く, 特に最大值力平均値よりも極めて大きくなって いる部分も存在する .

\section{（2）路面堆積負荷の平面マップ}

次に路面堆積負荷の空間分布特性を調へるために，大 堀川流域全体における SS と P-CODの空間マップを図5 に示す . これによると，流域の南部と北部の数箇所に おいて, 非常に大きな濃度值がSS や P-COD で見られて いる.しかしながら, 弚れらの地点はスポット的に散在 している.なお，流域全体における路面上のノンポイン 卜污染源モニタリングを行うには,今回の 30 点のみで十 分かどうか議論の余地があり, 今後, さらに多地点にお ける調査を継続して行う必要があ. 光のためには, 簡 便に多地点調査を行うことか容易な模擬降雨法は有力な 観測ツールとなり得るものと考えられる .

\section{6. まとめ}

降雨流出過程を簡便に模疑しつつ,多地点·多時点調査 力容易な模疑降雨法を用いて 富栄養化力著しい手賀沼に 流入する大堀川流域全体にわたる路面上のノンポイント 污染源調査を実施した .また，既存のモニタリング手法で あるブラシを用いた堆積物採集法も適用して 二つの手法 により計測された路面堆積負荷量を比較・検討した .弚の 結果 ,ブラシを用いた堆積物採集法による採取量は,模疑 


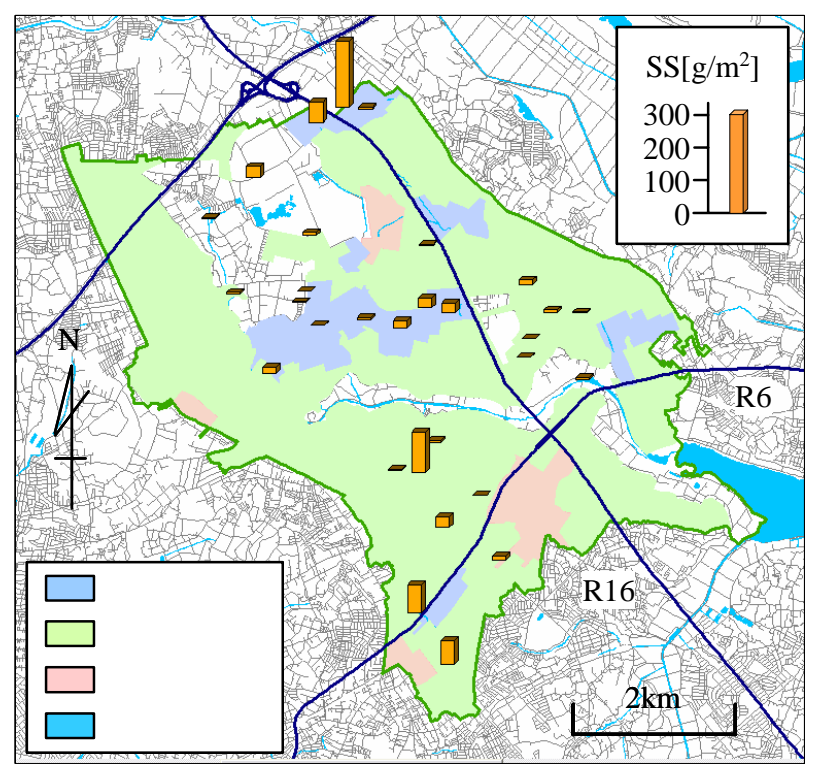

( a) SS

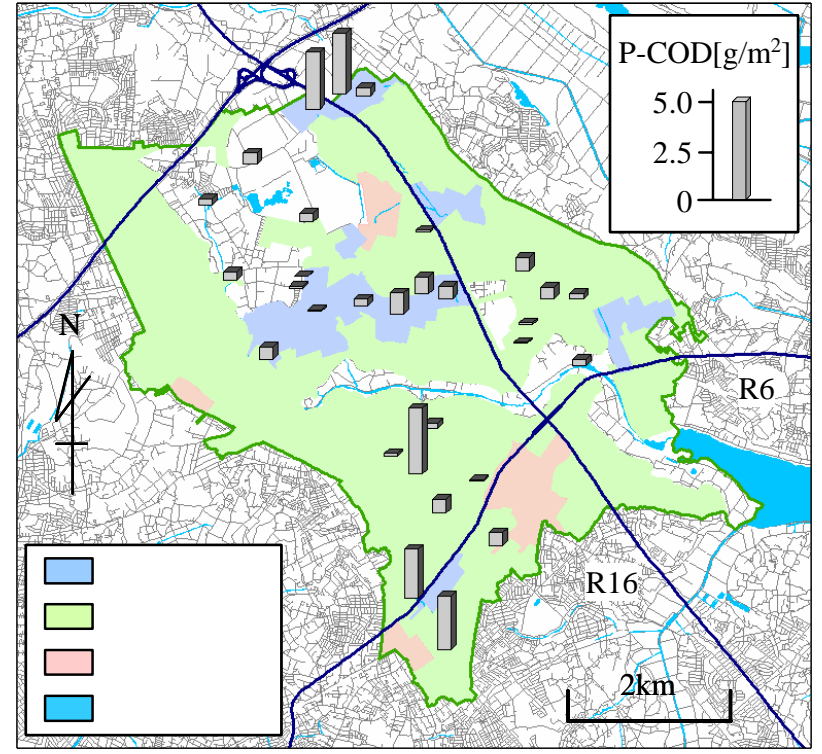

( b) P-COD

図- 5 大堀川流域における SS と P-COD の空間分布

降雨法よりも 1 オーダー程度大きいことか沶された この ような傾向は，著者らか行った室内実験と類似しており， 現地調査においても模疑降雨法の有用性力確忍された .

また，工業系地域と住居系地域における路面堆積負荷 環境を比べたところ，堆積物採集法による結果ては，工 業系地域における路面堆積負荷力淮居系地域よりも非常 に大きい，という既存の知見 ${ }^{1)}$ と類似する結果力得られ た。弚れに対して，模擬降雨法を用いた場合には，両地 域における負荷特性の違いはほとんど見られなかった . この結果より，堆積物採集法は，降雨時に流出する成分 よりも過乘に路面塵埃を採取したため，工業系地域にお ける路面堆積負荷量を過大に評価したものと考えられる． 今後，模擬降雨法を用いて調査地点・地域をさらに拡 大し , 路面上のノンポイント污染源の実態を明らかにし ていく予定である.

謝辞：本調査を行う際には, 東京理科大学理工学部土木 工学科水理研究室学生諸氏には多大なる御助力を頂いた . また , 水質分析の際に, 同学科出口浩教授に樣々な便宜 を図って頂いた . 本研究の一部は, 科学研究費補助金基 盤研究 (C) (2) (研究代表者: 二瓶泰雄), 下水道振興 基金研究助成金 (研究代表者: 二瓶泰雄), 文部科学省・ 私学学術フロンティア(2005)によるものである .ここに 記して謝意を表する。

\section{参考文献}

1) 和田安彦：ノンポイント污染源のモデル解析, 技報 堂出版, pp.1-214, 1990 .

2) 古米弘明: 都市域の雨天時污濁負荷流出解析の現状と課題, 水環境学会誌, Vol.25, No.9, pp.524-528, 2002.
3）武田育郎: 水と水質環境の基礎知識 ,オーム社 ,pp.1-198， 2001 .

4) 小野芳朗, 貫上佳則, 小田美光, 宗宮功 : 道路路面排水中 の多環芳香族化合物二ト口誘電体由来の遺伝毒性評価, 水 環境学会誌, Vol.20, No.11,pp.738-745, 1997.

5）村上道夫, 中島典之, 古米弘明 : 多環芳香族炭化水素類 (PAHs)含有率と产のプロファイルに基づく粒径画分ごと の道路・屋根堆積塵埃の識別，水環境学会誌，Vol.26,No.12， pp.837-842, 2003.

6)砂田岳彦, 二瓶泰雄, 水野智之, 今野篤 : 路面堆積物の簡 易モニタリング手法の提案, 水工学論文集, Vol.49, pp.1573-1578, 2005 .

7) 二瓶泰雄, 砂田岳彦, 水野智之 : 模擬降雨流出水採取法に 基づく路面塵埃環境の時間的・空間的変動特性の把握 , 水 環境学会誌, 2005 (投稿中).

8）（社）日本下水道協会:下水試験方法上巻 -1997 年版 - , pp.116-201，1997.

( 2005.9.30受付) 